\title{
Combination of Genetic Algorithm and Inverse Solution Technique for Estimating the Hydraulic Properties of Unsaturated Soft Rock
}

\author{
Min MAUNG MAUNG* ${ }^{*}$, Kunio WATANABE* ${ }^{*}$ Tai SASAKI** \\ and Masahiko OSADA*
}

\begin{abstract}
Unsaturated hydraulic property (relation between the water retention curve and hydraulic conductivity function) of soft rock must be properly estimated for analyzing the saturated-unsaturated groundwater flow such as the flow around a tunnel, rock surface and so forth. In this study a practical technique for estimating the unsaturated hydraulic property of soft rock was developed on the basis of the Campbell model and Genetic Algorithm (GA). The major objectives of the present study are the following two; 1) investigation whether or not the Campbell model can be applied to soft rock for approximating the unsaturated hydraulic properties and 2) application of GA technique for estimating two parameters included in the Campbell model. These parameters were estimated through the inverse analysis of the transient change of evaporation rates from a surface of disk shaped specimen of Tertiary sedimentary rock which are sampled from the Rokkasho area, Aomori prefecture. Two transient evaporation experiments under different atmospheric conditions were proposed for the estimation. The Campbell's parameters of 13 soft rock specimens ( 5 sandstone and 8 tuff breccia specimens) were estimated through those types of experiments. As the results it was clearly found that the transient change of evaporation rates can be well fitted by the Campbell model except for the region of low saturation and this fact implies that the Campbell model can be applied to the soft rock. And also it was found that, the GA is a promising technique for parameters estimation in the inverse solution method. It can be concluded that the techniques are practically for estimating the unsaturated hydraulic properties of soft rock.
\end{abstract}

Key words : unsaturated hydraulic properties, Campbell model, evaporation measurements, genetic algorithm

\section{Introduction}

Groundwater flow in unsaturated soft rock is relating to many problems such as the fracture creation around a tunnel due to drying, salt crystallization on rock surface, etc. In recent, the evaluation of those phenomena became very important for developing a safe way of hazardous waste disposal in the tunnels constructed in soft rock. During the operation phase of the disposal, waste will be transported and settled in the tunnels under the ventilation

* Geosphere Research Institute of Saitama University (会員)

** Japan Nuclear Fuel Limited (JNFL)(会員) condition. Unsaturated zone may be partly formed around a tunnel wall under this condition, and the rock behind the wall may be damaged by the creation of fractures and the salt crystallization occurring in the drying process. One of the most important points for evaluating those phenomena is the estimation of saturatedunsaturated hydraulic properties of soft rock. The hydraulic properties are the relations among the water retention curve, $h(\theta)$, and the hydraulic conductivity function, either $k(\theta)$ or $k(h)$, where $\theta$ is the saturation ratio, $h(\theta)$ is the capillary head and $k(\theta)$ is the relative hydraulic conductivity.

There are essentially two techniques for the 
estimation of unsaturated hydraulic properties of soil and rock. One is the direct measurement technique that was proposed by some previous researchers (BRUCE et $a l^{1}{ }^{1}$ and GARDNER et $\left.a l .^{2)}\right)$. Although the direct technique has been adopted for soil, the application to rock may be difficult because of high suction force generated in the unsaturated rock specimen and the water flowing in the specimen is too much small for the accurate measurement. Another technique is so called "Inverse solution technique" and the efficiency of this inverse method to estimate the unsaturated hydraulic properties were also reported by some previous researchers (KOOL et $a l .{ }^{3,4)}$, ECHING et $a l_{.}{ }^{5)}$ and WATANABE et $a l^{6)}$ ). The inverse solution method involves analytical or numerical solution of the transient flow induced under some fixed initial and boundary conditions. Several types of experiments were proposed by many researchers to generate the flow in the unsaturated soil/rock specimens that can be easily analyzed. For example, KOOL et $a l .^{3)}$ proposed one-step outflow experiment, ECHING et $a l^{5)}$ and VAN DAM et al. ${ }^{7)}$ used the multi-step outflow experiments. In recent, the flow induced by the evaporation have been proposed and used for the estimation by some researchers (for example, WATANABE et $a l^{6}{ }^{6}$, ALI et $a l^{8}{ }^{8}$ and FUJIMAKI, et $\left.a l^{9}{ }^{9}\right)$.

Non-linear Richards's equation (RICHARDS ${ }^{10}$ ) have been commonly used in the analysis of unsaturated flow. The unsaturated hydraulic properties in this equation should be used and some models have been proposed for soil by previous researchers (for example, BROOKS et $a l .{ }^{11)}$, MUALEM $^{12)}$, CAMPBELL ${ }^{13)}$ and VAN GENUCHTEN $\left.^{14}\right)$. If those models can be used as also the model for soft rock, it can be used in the inverse solution technique for estimating the unsaturated hydraulic properties as soil. Some conventional methods have been already proposed in the inverse solution technique mainly for analyzing non-linear Richards's equation. For example, Newton Raphson method and Levenberg-Marquardt method etc. were proposed by CAMPBELL ${ }^{15)}$, ALI et $a l^{8)}$, FUJIMAKI et $a l^{\left.9{ }^{9}\right)}$ and SIMUNEK et al. ${ }^{16)}$. These authors mainly used the Campbell model for estimating the unsaturated hydraulic properties of soil. If the Campbell model is also applied for soft rock, the estimation technique can be easily developed using the results of previous researchers. So that, one of the major objectives is focused on investigate whether or not the
Campbell can be applied to soft rock.

The equations of the Campbell model are defined with two parameters. For the estimation of these parameters by the inverse solution technique, Genetic Algorithm (GA) is applied in this study. Recently, GA has been frequently applied to solve science and engineering problems (for example, GWO ${ }^{17)}$, KARPOUZOS et $a l .{ }^{18)}$, AMOR et al. ${ }^{19)}$, UNSAL et al. ${ }^{20)}$ and SOHAIL et $\left.a l .{ }^{21}\right)$. And it was reported that the technique is a powerful tool for estimating any parameter sets. The application of GA for the parameter estimation is also studied. The objectives of this study are the following two; 1) to study the applicability of the Campbell model to soft rock and 2) to examine on the accuracy and efficiency of GA technique for estimating the parameters in Campbell model.

\section{Methodology}

There are two major problems in the application of the inverse solution technique for the estimation of parameters as follows; 1) generation of unsaturated flow under simple initial and boundary conditions and 2) estimation of two parameters included in the Campbell model. In this study one dimensional unsaturated flow in a disk shaped rock specimen induced by evaporation from a surface was generated and GA was adopted for the parameters estimation.

\subsection{Transient flow induced by evaporation}

As the initial condition, the disk shaped rock specimens were fully saturated by submerging in a container that is filled with distilled water and sucking air by a vacuum pump. Two types of evaporation experiments, experiment-I and experiment-II, were conducted. Experiment-I was carried out under the constant temperaturehumidity condition and experiment-II was conducted in variable temperature-humidity condition.

\subsubsection{Experiment-I (under constant tempera- ture-humidity condition)}

The experiment-I was carried out in a controlled temperature and humidity chamber, and evaporation rate was calculated from the weight changes of the specimen. Temperature and the humidity in the chamber were kept at 25 ${ }^{\circ} \mathrm{C}$ and around $40 \%$, respectively, at least one hour before the start of the experiment. The temperature and humidity reach a steady condition at 30 minutes after the start of the operation of the chamber. However, the 
temperature variation of $\pm 0.5^{\circ} \mathrm{C}$ and humidity variation of $\pm 5 \%$ were observed in the chamber during the period of experiment. Previous researchers reported that these small variations are not so much influence on the evaporation measurements ${ }^{8)}$.

Both the side wall and the bottom of the disc shaped specimens were completely

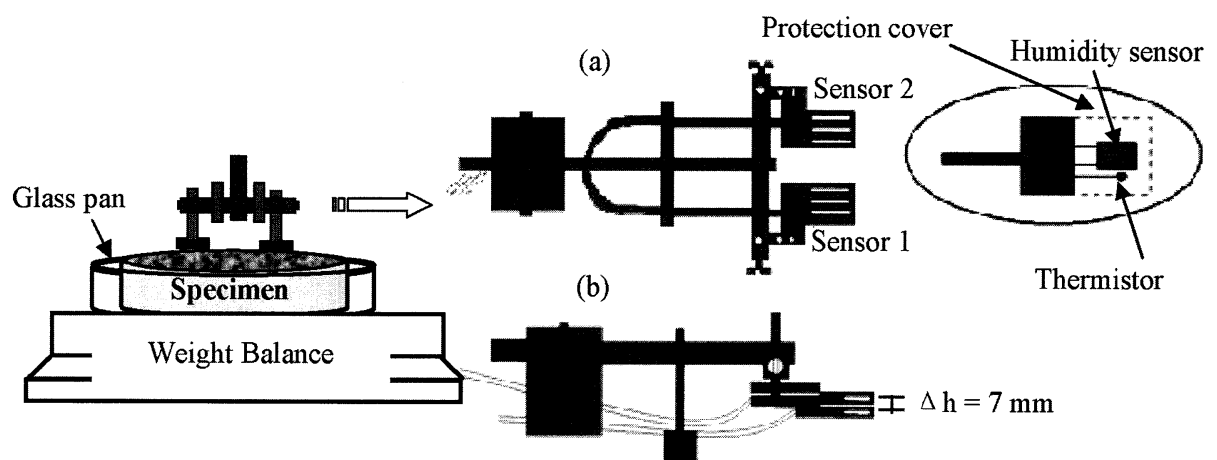

Fig. 2 Experimental condition for transient evaporation measurement (Experiment-II) and the schematic diagram for two-sensor type evaporation meter

(a) Top view, (b) Side view

sealed with silicone sealant to avoid the evaporation from these surfaces. Therefore, the specimen was allowed to evaporate from the surface of the specimen and gradually dried. A schematic diagram of the experimental apparatus is illustrated in Fig. 1. During the evaporation measurement, the weight changes of specimen are measured by an electric balance at one hour time intervals. Then, the average evaporation rate in each one hour interval is calculated from the relative weight loss. The evaporation experiment was terminated when the weight changes of the rock specimen measured at one hour time interval is less than $0.01 \mathrm{~g}$ (the minimum digits of weight balance).

\subsubsection{Experiment-II (under room condition)}

The second type of the evaporation experiment was conducted by using two-sensor type evaporation meter (WATANABE ${ }^{22)}$ ) under the room condition (average temperature was $18^{\circ} \mathrm{C}$ and average humidity was $60 \%$ ). The accuracy of the two-sensor type evaporation meter has been reported by WATANABE et $a l^{222,23)}$ and KYI MYINT THWIN et $a l .{ }^{24)}$, and one of the advantage of this type of experiment is the applicability even in the field. The evaporation meter is mainly composed of two couples of humidity sensor and thermistor. The data measured by those sensors are sent to a computer to calculate the absolute humidity gradient between two

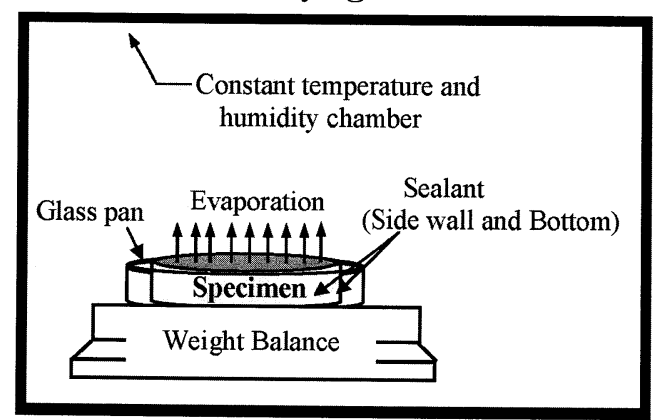

Fig. 1 Experimental condition for transient evaporation measurement (Experiment-I) different heights from the surface of the rock specimen, and evaporation rate can be calculated with multiplying the diffusion coefficient of vapor in air to the absolute humidity gradient. The schematic diagram of experimental set up and the two-sensor type evaporation meter are illustrated in Fig. 2. Specimens were saturated and the bottom and side walls were sealed as the same way in experiment-I. The evaporation measurement was stopped when the evaporation rate from the top surface of specimen become the value is less than or equal to $0.1 \mathrm{~mm} /$ day (See in Fig. 10.b).

\subsection{Basic equations of the flow induced by evaporation}

\subsubsection{Vapor flux from a wet soil/rock surface}

Both the liquid and the vapor flows in the disc shaped rock specimens are considered in the analysis. CAMPBELL ${ }^{15)}$ has reported that the vapor flow from the surface of soil specimen under the external atmospheric conditions can be estimated when the initial potential evaporation rate $\left(E_{\mathrm{p}}\right)$ is known. The vapor flux $\left(q_{\mathrm{vs}}\right)$ at the soil/rock surface can be written by using $E_{\mathrm{p}}$ as;

$$
q_{\mathrm{vs}}=E_{\mathrm{p}} \frac{\left(h_{\mathrm{s}}-h_{\mathrm{a}}\right)}{\left(1-h_{\mathrm{a}}\right)}
$$

where $h_{\mathrm{s}}$ is the soil/rock surface humidity, and $h_{\mathrm{a}}$ is the air humidity. $q_{\mathrm{vs}}$ is the same as the evaporation rate. For the calculation of evaporation rate change during the experiment, the liquid and the vapor flows in the soil/rock must be taken into account.

\subsubsection{Two phase flow in soil-rock}

(1) Liquid-phase transport

The vertical liquid flow in unsaturated porous media is described by the Darcy-Buckingham equation;

$$
q_{1}=-k\left[\left(\frac{\partial \Psi}{\partial z}\right)+1\right]
$$


where $q_{1}$ is the unsaturated water flux $\left(\mathrm{kgm}^{-2} \mathrm{~s}^{-1}\right.$ $\left.\sim 0.001 \mathrm{~ms}^{-1}\right), k(\theta)$ is the rock hydraulic conductivity $\left(1 \mathrm{kgsm}^{-3} \approx 0.0098 \mathrm{~ms}^{-1}\right), \Psi(\theta)$ is the matric potential of water $\left(<0,1 \mathrm{Jkg}^{-1} \sim 0.102 \mathrm{~m}\right.$ of water), and $z$ is the vertical coordinate (positive upward, $\mathrm{m}), \theta$ is the volumetric water content $\left(\mathrm{m}^{3} \mathrm{~m}^{-3}\right)$. The solution of equation (2) required the knowledge of the hydraulic functions $k(\theta)$ and $\Psi(\theta)$. To formulate these values, Campbell model (CAMPBELL ${ }^{13)}$ ) is used and then the applicability of the model was studied. The Campbell model is written by the following equations ${ }^{13}$;

$$
\begin{aligned}
& \theta=\theta_{\text {sat }}\left(\frac{\Psi_{\mathrm{e}}}{\Psi}\right)^{\frac{1}{b}} \\
& k=k_{\text {sat }}\left(\frac{\theta}{\theta_{\text {sat }}}\right)^{m}
\end{aligned}
$$

where $\theta_{\text {sat }}$ is the saturated water content $\left(\mathrm{m}^{3} \mathrm{~m}^{-3}\right)$, $\Psi_{\mathrm{e}}$ is the air entry potential $\left(\mathrm{Jkg}^{-1} \sim 0.102 \mathrm{~m}\right.$ of water), $b$ is soil/rock parameter (defined as the slop of $\log \Psi$ verses $\log \theta$ plot), $k_{\text {sat }}$ is the saturated hydraulic conductivity $\left(\mathrm{kgsm}^{-3} \sim 0.0098 \mathrm{~ms}^{-1}\right)$, and $m=2 b+3$.

\section{(2) Vapor-phase transport}

The flux density of vapor $\left(q_{v}\right)$ in soil/rock is described by Fick's Law:

$$
q_{\mathrm{v}}=-D_{\mathrm{v}} \frac{\mathrm{d} c_{\mathrm{v}}}{\mathrm{d} z}
$$

where $c_{\mathrm{v}}$ is the soil/rock vapor concentration $\left(c_{\mathrm{v}}\right.$ $\left.=c_{\mathrm{v}}{ }^{*} h_{\mathrm{r}}\left(\mathrm{gm}^{-3}\right)\right), h_{\mathrm{r}}$ is the relative humidity and $c_{\mathrm{v}}{ }^{*}$ is the saturation vapor concentration at soil/rock temperature and $D_{\mathrm{v}}$ is the water vapor diffusivity in soil/rock can be expressed in Eq. (6) by previous researchers ${ }^{8), 15)}$;

$$
D_{\mathrm{v}}=0.66 D_{0}\left(\theta_{\mathrm{sat}}-\theta\right)
$$

where $D_{0}$ is the diffusion coefficient for vapor water in air $\left(\mathrm{m}^{2} \mathrm{~s}^{-1}\right), \theta_{\text {sat }}$ is the saturated water content $\left(\mathrm{m}^{3} \mathrm{~m}^{-3}\right)$ and $\theta$ is the volumetric water content $\left(\mathrm{m}^{3} \mathrm{~m}^{-3}\right)$. The diffusivity of water vapor in air depends on the temperature of the air, as well as its pressure. The following relationship is often used to express pressure and temperature dependence of diffusivity:

$$
D_{0}\left(\mathrm{~m}^{2} \mathrm{~s}^{-1}\right)=\frac{2.12}{(10)^{5}}\left\{\frac{T_{\mathrm{a}}}{273.16}\right\}^{2}\left\{\frac{1,013}{P}\right\}
$$

where $T_{\mathrm{a}}$ is the air temperature $(\mathrm{K})$ and $P$ is the pressure of the air $(\mathrm{hPa})$. Under the constant atmospheric conditions and then, $\mathrm{d} c_{\mathrm{v}} / \mathrm{d} z=c_{\mathrm{v}}{ }^{*} \mathrm{~d} h_{\mathrm{r}} /$ $\mathrm{d} z$. So that, Eq. (5) can be rewritten as;

$$
q_{\mathrm{v}}=-D_{\mathrm{v}} c_{\mathrm{v}}{ }^{*} \frac{\mathrm{d} h_{\mathrm{r}}}{\mathrm{d} z}
$$

The relative humidity of the air in the soil/ rock pore space $\left(h_{\mathrm{r}}\right)$ can be expressed as a function of water potential $(\Psi)$ as;

$$
h_{\mathrm{r}}=\exp \left(\frac{\Psi M_{\mathrm{w}}}{R T_{s}}\right)
$$

where $M_{\text {w }}$ is the molar mass of water $(0.018 \mathrm{~kg}$ $\left.\mathrm{mol}^{-1}\right)$ and $R$ is a universal gas constant (8.3143 $\left.\mathrm{Jmol}^{-1} \mathrm{~K}^{-1}\right), T_{\mathrm{s}}$ is the soil/rock surface temperature $(\mathrm{K})$. Applying the chain rule, $\mathrm{d} h_{\mathrm{r}} / \mathrm{d} z=\left(\mathrm{d} h_{\mathrm{r}} /\right.$ $\mathrm{d} \Psi)(\mathrm{d} \Psi / \mathrm{d} z)$.

$$
q_{\mathrm{v}}=-D_{\mathrm{v}} c_{\mathrm{v}}{ }^{*} h_{\mathrm{r}} \frac{M_{\mathrm{w}}}{R T_{\mathrm{s}}} \frac{\mathrm{d} \Psi}{\mathrm{d} z}=-k_{\mathrm{v}} \frac{\mathrm{d} \Psi}{\mathrm{d} z}
$$

where $k_{\mathrm{v}}$ is vapor conductivity. Eq. (10) is added to the liquid flow equation (Eq. (2)) to calculate the total water flux in two phases (liquid and vapor phases).

\subsection{Assumptions}

Although the evaporation change can be theoretically described, some approximations should be used in the estimation process. These assumptions are mainly coming from the approximation of air humidity $\left(h_{\mathrm{a}}\right)$ and the rock surface temperature $\left(T_{\mathrm{s}}\right)$ in Eq. (1) and Eq. (9). Particularly those problems are more prominent in experiment-II. For experiment-I, air humidity $\left(h_{\mathrm{a}}\right)$ in Eq. (1) can be thought as the same as in the chamber's humidity $(40 \%)$ and the rock surface temperature $\left(T_{\mathrm{s}}\right)$ in Eq. (9) is assumed to be constant $\left(25^{\circ} \mathrm{C}\right)$. In the analysis of experiment -II, air humidity $\left(h_{\mathrm{a}}\right)$ was approximated by average room humidity (60\%). For this approximation on $h_{\mathrm{a}}$, the condition is that the humidity conditions should not be much changed is needed during experiment. And the rock surface temperature $\left(T_{\mathrm{s}}\right)$ is assumed as average temperature $\left(18{ }^{\circ} \mathrm{C}\right)$ measured by two sensors (sonsor-1 and sonsor-2). When surface temperature $\left(T_{\mathrm{s}}\right)$ was not large different from air temperature $\left(T_{\mathrm{a}}\right)$, the formula approximation will not so much influence. From these approximations, it can be said that the experiment-II should not be performed in the field because $T_{\mathrm{a}}$ is temporally changed and $T_{\mathrm{s}}$ can not be estimated especially under the sunshine condition. Although the experiment-II were conducted in the room, there may be possibility that the estimated Campbell's parameter values between experiment-I and experiment-II may not be completely the same values due to experimental conditions and assumptions used in the calculation.

\subsection{Inverse solution technique}

An inverse solution technique involves the 


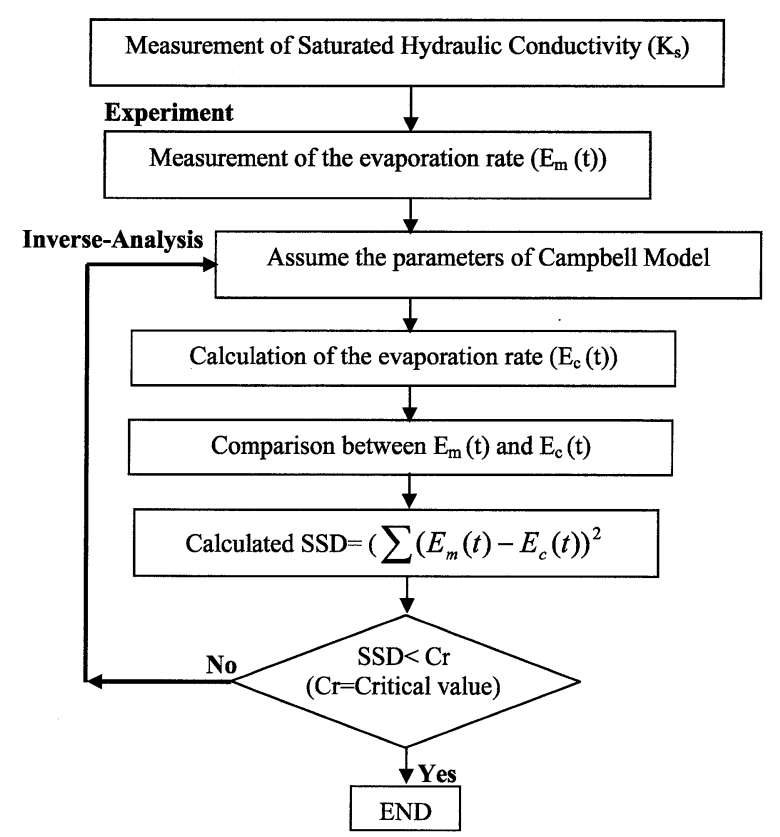

Fig. 3 The procedure of an inverse solution technique (Ali et $a l .^{8}$ )

indirect estimating the parameters in the Campbell model ( $b$ and $\Psi_{\mathrm{e}}$ ). The similar techniques of inverse solution method has been reported by previous researchers (ECHING et $a l .{ }^{25)}$, ALI et $a l .^{8)}$ and HASSAN et $\left.a l^{26)}\right)$. Fig. 3 schematically shows the procedure of the inverse solution technique. In this procedure, evaporation rates $\left(E_{\mathrm{c}}(t)\right)$ during the period of experiment are calculated on the basis of the flow equations with the assumed parameters of Campbell model $\left(b\right.$ and $\Psi_{\mathrm{e}}$ ). Then the measured evaporation rates $\left(E_{\mathrm{m}}(t)\right)$ and calculated evaporation rates $\left(E_{\mathrm{c}}(t)\right)$ are compared and the sum of square differences $(S S D)$ is evaluated. When the $S S D$ values is big, Campbell's parameters are changed and calculated again the $E_{\mathrm{c}}(t)$ and $S S D$. The changes of the parameters were performed by GA technique. When the sum of the square differences $(S S D)$ is less than the critical value $(\mathrm{Cr})$, the iterations are stopped. Critical value $(\mathrm{Cr})$ in the inverse solution technique procedure can be defined as the minimum value of sum of the square differences ( $S S D$ ) in the calculation $^{8,25)}$. However in this study the iterations were stopped when the SSD becomes almost constant. This technique is explained in the following section (See section 2.5).

\subsection{Genetic Algorithm application to parameter estimation}

Genetic Algorithm (GA) has been used for parameter identification and for solving the optimization problems. HOLLAND ${ }^{27)}$ developed this technique which is popularized by
GOLDBERG ${ }^{28)}$. GA is based on the Darwiniantype survival of the fittest strategy, and it operates through its genetic operators like selection, crossover and mutation to produce stronger individuals ${ }^{21)}$. Each individual in the population represents a potential solution to problem (in this case, the combination of parameters $b$ and $\Psi_{\mathrm{e}}$ ) and is referred as a chromosome. Chromosome is assembled from a set of genes (substrings or bits in other words) that can be binary digits (the row of 0 and 1), integers or real numbers ${ }^{29), 30}$. In this study, the 22 length of binary digits defined from real numbers of $b$ and $\Psi_{\mathrm{e}}$ were used. The fitness value is a value related to the performance of the chromosome to the specific problem. In this study, the fitness value $(F)$ is defined as the value to minimize the sum of square differences ( $S S D)$, that is:

$$
F=\frac{1}{\sum_{t=1}^{n}\left(E_{\mathrm{m}}(t)-E_{\mathrm{c}}(t)\right)^{2}}=\frac{1}{S S D}
$$

where $E_{\mathrm{m}}(t)$ and $E_{\mathrm{c}}(t)$ are the measured and simulated evaporation rates each time step as mention in Fig. 3. The population size (PS) is the number of individuals in a generation that are kept constant during GA calculation. Based on the previous GA studies ${ }^{31) ~ 33)}$ we have experienced that, increasing the population size enables the GA to search more points and thereby obtain a better result. However, when the population size becomes large, computation time increases. For that reason, we performed some initial calculations of GA (i.e. trials of population size) to check the performance of GA in this study. From these initial calculations it was found that, the small population size (i.e. $P S<30$ ) gave the performance of GA tend to converge very fast. However, the results are often different from the minimum (global minimum) $S S D$ value in the GA's performance. If we increasing the population size (i.e. $P S=70 \sim 100$ ), the performance of GA gave slow convergence. This convergence takes longer time for the optimization of SSD values with no substantial gain in the performance of GA. From these trials we decided that, the population size (PS) of 50 is to get a fast calculation and a good performance of GA in this study.

Three basic genetic operators: selection, crossover and mutation are the essential procedures for producing new and unique children. In this paper, the fitness-proportional or roulette wheel selection $^{27)}$ is used with elitism that is a process in which the best chromosome of each generation is 
carried over to the next generation, to ensure that the best chromosome is saved during the evolutionary process. Various crossover techniques such as single-point crossover, two-point crossover and uniform crossover $^{29)}$ have been proposed by previous researchers. In the present study, we used the single point crossover method. Mutation action was carried out to randomly flip some of the bits (changing 0 to 1 or 1 to 0 ) in the chromosome. The mutation keeps the diversity in the genes of population and stops it from a premature convergence. DANDY et al. . $^{34)}$ suggested that a good performance of the GA may be obtained by using a high crossover probability (i.e. 0.5 to $1.0)$ and a low mutation probability (i.e. 0.001 to 0.05 ). However, these parameters of GA are also depending on the problems itself. Therefore, we examined many trials GA calculations for all rock specimens with different alternatives and certainly different GA parameters values for searching combination for the best performance of GA in our study. After some trials of GA calculations, we observed that the probability of crossover rate $\left(P_{\mathrm{c}}\right)$ is equal to 0.6 and the probability of mutation rate $\left(P_{\mathrm{m}}\right)$ is equal to 0.005 are get the best optimum $S S D$ value (global minimum $S S D$ ) in the calculation and gave the good performance of GA for all rock specimens. Fig. 4 displays the flow chart of calculation in which GA is used in the inverse solution method. The process is composed of the following steps:

1. Define the number of genes in the chromosome. In this study, the numbers of genes are two and these genes are presenting the parameters of the Campbell model $\left(b\right.$ and $\Psi_{\mathrm{e}}$ ).

2. Define the range of the genes (maximum and minimum values for $b$ and $\Psi_{\mathrm{e}}$ ), and the population size $(P S)$. In this study, the range is given on the basis of empirical calculation, and the population size (PS) is fixed as 50 .

3. Generate the chromosomes which are composed of genes ( $b$ and $\Psi_{\mathrm{e}}$ ) defined by random
Define the number of genes of chromosome is constructed (The two parameters of the Campbell model, i.e. $\mathrm{b}$ and $\psi_{e}$ )

Define the range of each gene ( $\mathrm{b}$ and $\psi_{e}$ ) and create the initial population of chromosomes in initial pool. (Population size $(\mathrm{PS})=50$ )

Generate chromosomes composed of genes defined by random number $(\mathrm{RN})$. And each gene of chromosome is binary in coded ( 0 and 1$)$.

Calculate $E_{c}(t)$ for every chromosome in initial pool and evaluate the SSD values and the fitness value (i.e. $F=1.0 / \mathrm{SSD}$ ).

Construct the Roulette wheel based on the fitness values (F).

Two parents are randomly select by roulette wheel selection.

Crossover parents by a single point crossover method with cross over rate probability $\left(\mathrm{P}_{\mathrm{c}}=0.60\right)$

Mutate genes of children by the binary mutation with the mutation probability $\left(\mathrm{P}_{\mathrm{m}}=0.005\right)$

Send 2 fittest individuals among 2 parents and 2 children to new pool

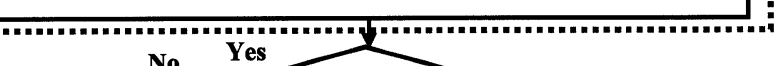

No

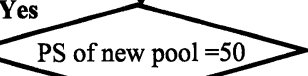

Yes
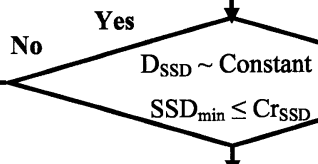

Select best genes ( $\mathrm{b}$ and $\psi_{e}$ ) of chromosome in accordance with best fitness value $(F)$

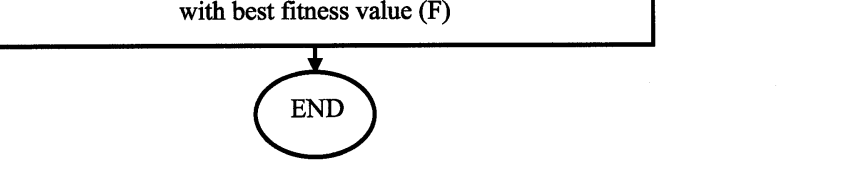

hart of GA application in the inverse solution technique number $(\mathrm{RN})$. And each gene in the chromosome is decoded to binary code (the row of 0 and 1 ). 4. Calculate the evaporation rate $\left(E_{\mathrm{c}}(t)\right)$ for every chromosome in the initial pool. Evaluate the sum of the square differences (SSD) and the fitness value $(F)$ of each chromosome (See in Eq. (11)).

5. Construct the Roulette wheel (selection operator) based on the fitness of each chromosome $(F)$. Roulette wheel randomly select the two chromosomes from the initial pool, which are called as the parent chromosomes.

6. Apply the single point crossover method (crossover operator) to the parent chromosomes in accordance with the crossover rate $\left(P_{\mathrm{c}}\right)$. One crossover point is selected randomly at the identical location in two parents. The first part (i.e. binary string before crossover point) of first parent and the second part (i.e. binary string after crossover point) of second parent are combined to form a new chromosome which is 
(a)
Parent chromosome-1 (P1)

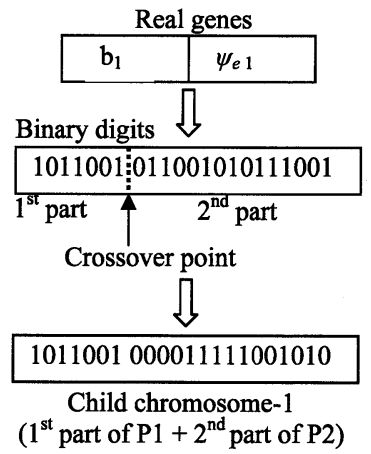

(b)

\begin{tabular}{|l|}
\hline 1011001000011111001010 \\
\hline Original child chromosome-1 \\
\hline 1011000000011111001010 \\
Mutated child chromosome-1
\end{tabular}

Parent chromosome-2 (P2)

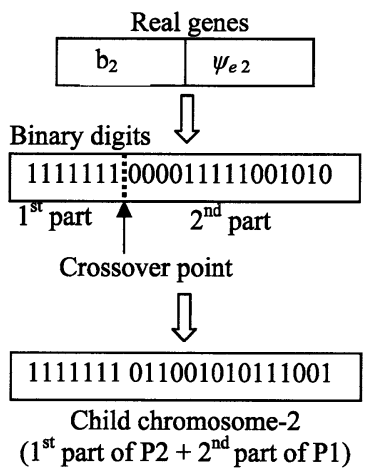

1111111011001010111001

Original child chromosome-2

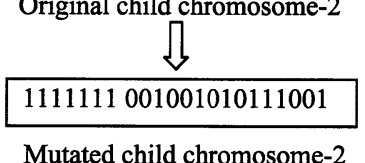

Fig. 5 The schematic diagram for (a) the single-point crossover procedure in parent chromosomes and (b) the mutation in the children chromosomes

called the child chromosome (offspring). And then the second part of first parent and the first part of second parent are recombined to form another child chromosome. The mutation operator is carried out in the children chromosomes to introduce changes in genes of child chromosome (i.e., if it has 0 value it is mutated as 1 or vice versa) according to a predetermine mutation probability $\left(P_{\mathrm{m}}\right)$. The schematic diagram for single point crossover and mutation procedures are illustrated in Fig. 5. In this study, total length of binary digits of chromosome was used as 44 .

7. The four chromosomes (2 parents and 2 children) are compared to each other on their fitness values. The best two (the chromosomes having the maximum and second maximum fitness values) are sent to a new pool and other two are destroyed. When the population size (PS) of new pool is same as the initial PS (i.e. PS $=50$ in this study), one generation cycle is to be complete and then GA is checked for stopping conditions. Every chromosome in the generation has different $S S D$ values (i.e. $D_{\mathrm{SSD}}=S S D_{\max }$ $-S S D_{\min }$ ) (See in Fig. 6). These different $S S D$ values are in the region between the maximum $S S D\left(S S D_{\max }\right)$ and the minimum $S S D\left(S S D_{\min }\right)$ in each generation. By the repetition of the GA process the difference between the maximum and the minimum $S S D$ values become smaller in the GA calculation. However, the difference $S S D$ value does not zero value due to the mutation

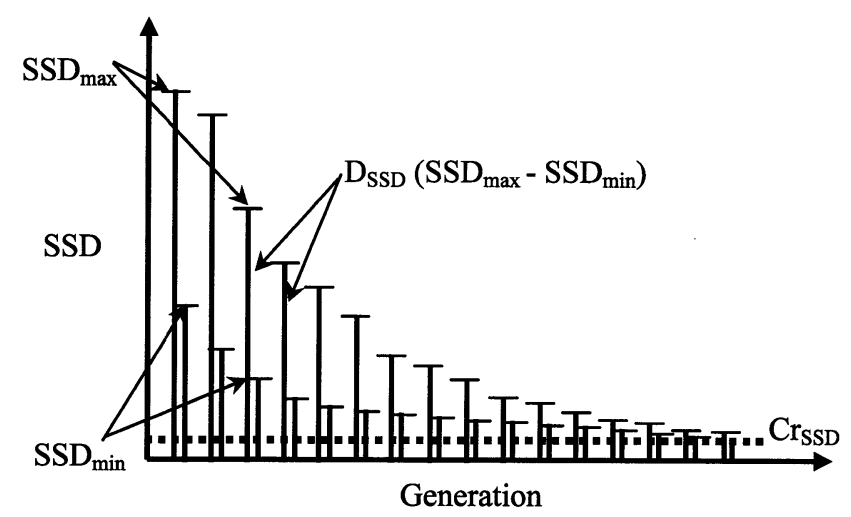

Fig. 6 Basic concept of $D_{\text {ssD }}$ and $C r_{\text {ssD }}$ in the generations during the GA process

operator.

8. For stopping the GA iterations process, two criterions are used in this study. The first criterion is that the difference of $S S D$ values ( $\left.D_{\text {SSD }}\right)$ in the generation is almost the constant. The second criterion is that, the minimum SSD $\left(S S D_{\min }\right)$ is less than or equal to critical value of $S S D$ ( $\mathrm{Cr}_{\text {SSD }}$ ) (See in Fig. 6). In this study $\mathrm{Cr}_{\text {sSD }}$ was defined as the minimum values of $S S D\left(S S D_{\min }\right)$ that was not changed with iteration. The critical value $\left(C r_{\text {SSD }}\right)$ is not the same for all rock specimens. Because the value of $\mathrm{Cr}_{\mathrm{SSD}}$ is changed due to the small error in evaporation measurements in experiment-I and experiment-II (See Fig. 9, 10.a and 10.b).

9. The best chromosome is selected by the best fitness value (i.e. the biggest value of $F$ ) in the generations. Hence, the genes of best chromosome represent the best fitness parameters of the Campbell model ( $b$ and $\Psi_{\mathrm{e}}$ ).

\section{Samples used for the hydraulic proper- ties estimation}

The 13 soft rock specimens were sampled from the Rokkasho-village, Aomori Prefecture in the northern area of the Mainland of Japan. The Neogene sedimentary rock called Takahoko formation is distributing over the area. The quaternary stratum about $10 \mathrm{~m}$ in thickness is covering the Takahoko formation. This formation is mainly consists of sandstone (or) siltstone (hereafter called as sandstone) and tuff breccia with pumices (hereafter refer as pumice tuff). Five sandstone specimens (SS-1 5) and eight pumice tuff specimens (PS-1 8) are used for the unsaturated hydraulic properties estimation. Before the estimation, the physical properties and saturated hydraulic conductivity of specimens were measured in the laboratory. The saturated hydraulic conductivities of the specimens are measured by a falling head test. 
Table 1 Physical property of soft rock specimens

\begin{tabular}{lllcccc}
\hline $\begin{array}{c}\text { Sample } \\
\text { Name }\end{array}$ & Rock Type & $\begin{array}{c}\text { Length } \\
(\mathrm{cm})\end{array}$ & $\begin{array}{c}\text { Diameter } \\
(\mathrm{cm})\end{array}$ & $\begin{array}{c}\text { Buck Density } \\
\left(\mathrm{g} / \mathrm{cm}^{3}\right)\end{array}$ & $\begin{array}{c}\text { Porosity } \\
(\%)\end{array}$ & $\begin{array}{c}\text { Sat. Hyd. }\left(\mathrm{k}_{\mathrm{s}}\right) \\
(\mathrm{cm} / \mathrm{sec})\end{array}$ \\
\hline & & & & & & \\
SS-1 & Sandstone & 3 & 9 & 1.81 & 0.42 & $4.0 \times 10^{-7}$ \\
SS-2 & Sandstone & 2 & 6 & 1.61 & 0.46 & $6.5 \times 10^{-7}$ \\
SS-3 & Sandstone & 2 & 6 & 1.56 & 0.46 & $7.5 \times 10^{-7}$ \\
SS-4 & Sandstone & 2 & 6 & 1.60 & 0.47 & $7.2 \times 10^{-7}$ \\
SS-5 & Sandstone & 2 & 6 & 1.60 & 0.46 & $7.1 \times 10^{-7}$ \\
PS-1 & Pumice Tuff & 3 & 9 & 1.55 & 0.60 & $5.7 \times 10^{-6}$ \\
PS-2 & Pumice Tuff & 3 & 9 & 1.70 & 0.52 & $4.2 \times 10^{-6}$ \\
PS-3 & Pumice Tuff & 2 & 7 & 1.46 & 0.58 & $4.8 \times 10^{-6}$ \\
PS-4 & Pumice Tuff & 2 & 7 & 1.53 & 0.52 & $3.6 \times 10^{-6}$ \\
PS-5 & Pumice Tuff & 2 & 7 & 1.55 & 0.56 & $4.6 \times 10^{-6}$ \\
PS-6 & Pumice Tuff & 2 & 7 & 1.56 & 0.55 & $4.4 \times 10^{-6}$ \\
PS-7 & Pumice Tuff & 2 & 7 & 1.53 & 0.53 & $5.3 \times 10^{-6}$ \\
PS-8 & Pumice Tuff & 2 & 7 & 1.53 & 0.50 & $3.3 \times 10^{-6}$ \\
\hline
\end{tabular}
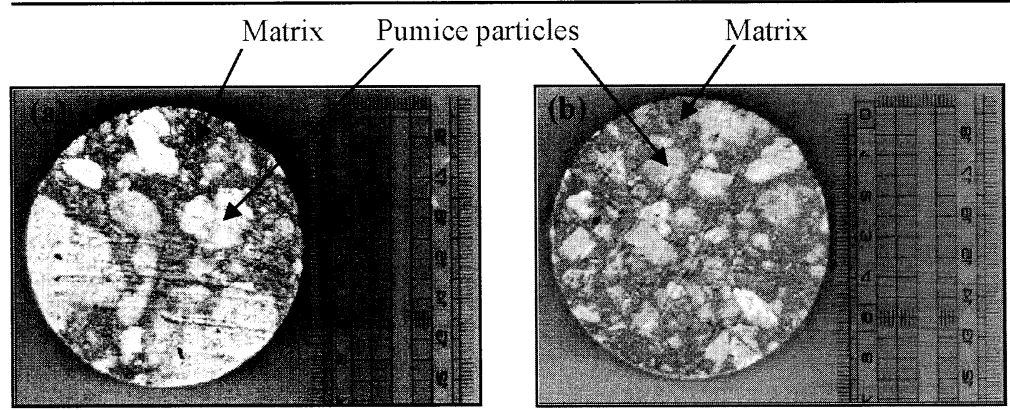

Fig. 7 The appearance of pumice particles of (a) PS-5 and (b) PS-7

The physical properties for the soft rock specimens are summarized in Table 1 . It is observed from this table that the saturated hydraulic conductivities $\left(k_{\mathrm{s}}\right)$ of pumice tuff specimens (i.e., $k_{\mathrm{s}}=3.0 \sim 6.0 \times 10^{-6} \mathrm{~cm} / \mathrm{sec}$ ) are around one order larger than sandstone specimens (i.e., $k_{\mathrm{s}}=4.0 \sim 7.0 \times 10^{-7} \mathrm{~cm} / \mathrm{sec}$ ). In this study, all sandstone specimens (SS-1 5 ) and the six pumice tuff specimens (PS-1 6) are analyzed by experiment-I and two pumice tuff specimens (PS-7, 8) are used in experiment-II. However, pumice tuff specimen (PS-8) is used once more in experiment-I for verification of Campbell's parameters in both experiments. It will be explain in section 4.3 .

The unsaturated feature of pumice tuff specimens may be different to each other due to the difference of the sizes of pumice particles contained. Fig. 7 shows the examples of the appearance of pumice particles on the evaporated surface area between PS-5 and PS-7. The particle size in PS-5 is bigger than the PS-7. Therefore, saturated as well as unsaturated hydraulic properties are different. On the other hand, the sandstone specimens are composed of small grains tightly cemented to each other. As shown by Fig. 8 , the sandstone specimens $(\mathrm{SS}-1 \sim 5$ ) looked texturally homogeneous. So that, the variation of the hydraulic properties of sandstone specimens is thought to be smaller as

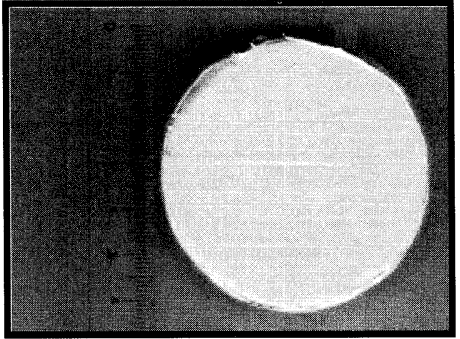

Fig. 8 The texturally homogeneous sandstone specimen

compared with pumice tuff specimens.

\section{Results and Discussions}

\subsection{Evaporation}

The measured transient change of evaporation rates obtained by experiment-I and experiment-II are summarized in Fig. 9, 10.a and 10.b. Calculated evaporation change with the selected best combination of $b$ and $\Psi_{\mathrm{e}}$ values are also illustrated in those figures. Fig. 9, Fig. 10.a are show the transient change of evaporation in experiment-I (i.e. constant temperature $25{ }^{\circ} \mathrm{C}$ and constant humidity of around $40 \%$ ) for all sandstone specimens and six pumice tuff specimens. From these figures it has been observed that the measured evaporation rates for sandstone specimens are nearly constant $(\sim 12$ $\mathrm{mm} /$ day) in the initial evaporation conditions, however, the initial evaporation rate for pumice tuff specimens are not constant $(8 \sim 18 \mathrm{~mm} /$ day). The larger variation of the initial evaporation rates for the pumice tuff specimens may be due to the pumice distribution. In the experiment-II under the room condition, the initial evaporation rates of two pumice tuff specimens (see in Fig. 10.b) are smaller values $(0.9 \sim 0.5 \mathrm{~mm} /$ day $)$. It may be due to the change of experimental conditions (i.e. lower temperature (average: $18{ }^{\circ} \mathrm{C}$ ) and higher humidity (average: $60 \%)$ ). It is clearly seen from those figures that the evaporation rate are rapidly changed in the course of the experiment (experiment-I and experiment-II) and the calculated change could well fit the experimental results.

\subsection{Performance of GA}

In this study, GA is used for the unsaturated hydraulic properties parameters estimation. GA is well performed to minimize the sum of the square differences ( $S S D)$ during the time of evaporation measurements. Fig. 11, 12.a and 12.b show the $S S D$ values during GA calculation for the sandstone and the pumice tuff specimens. 

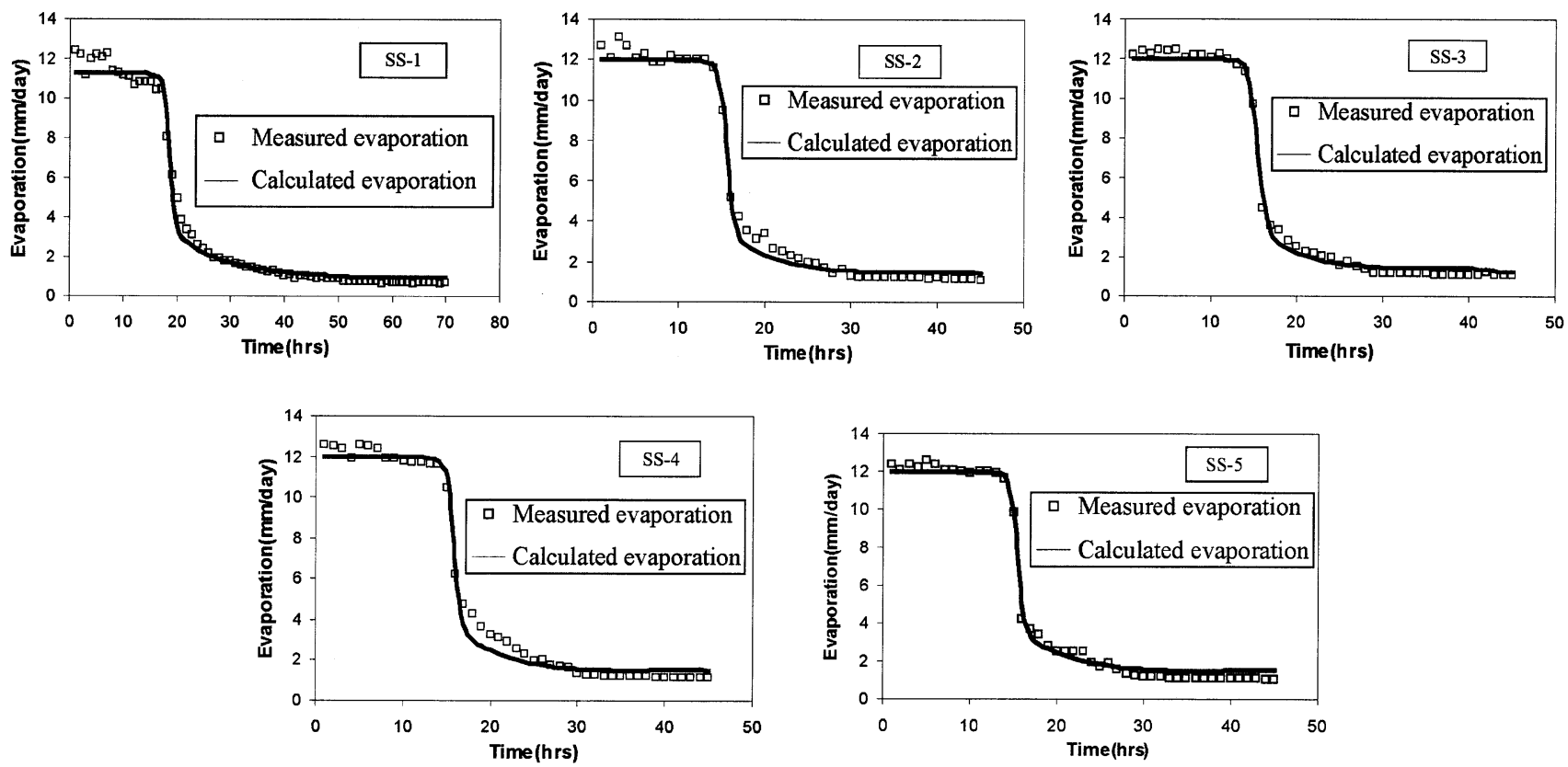

Fig. 9 Measured and calculated evaporation rates for the sandstone specimens (Experiment-I)
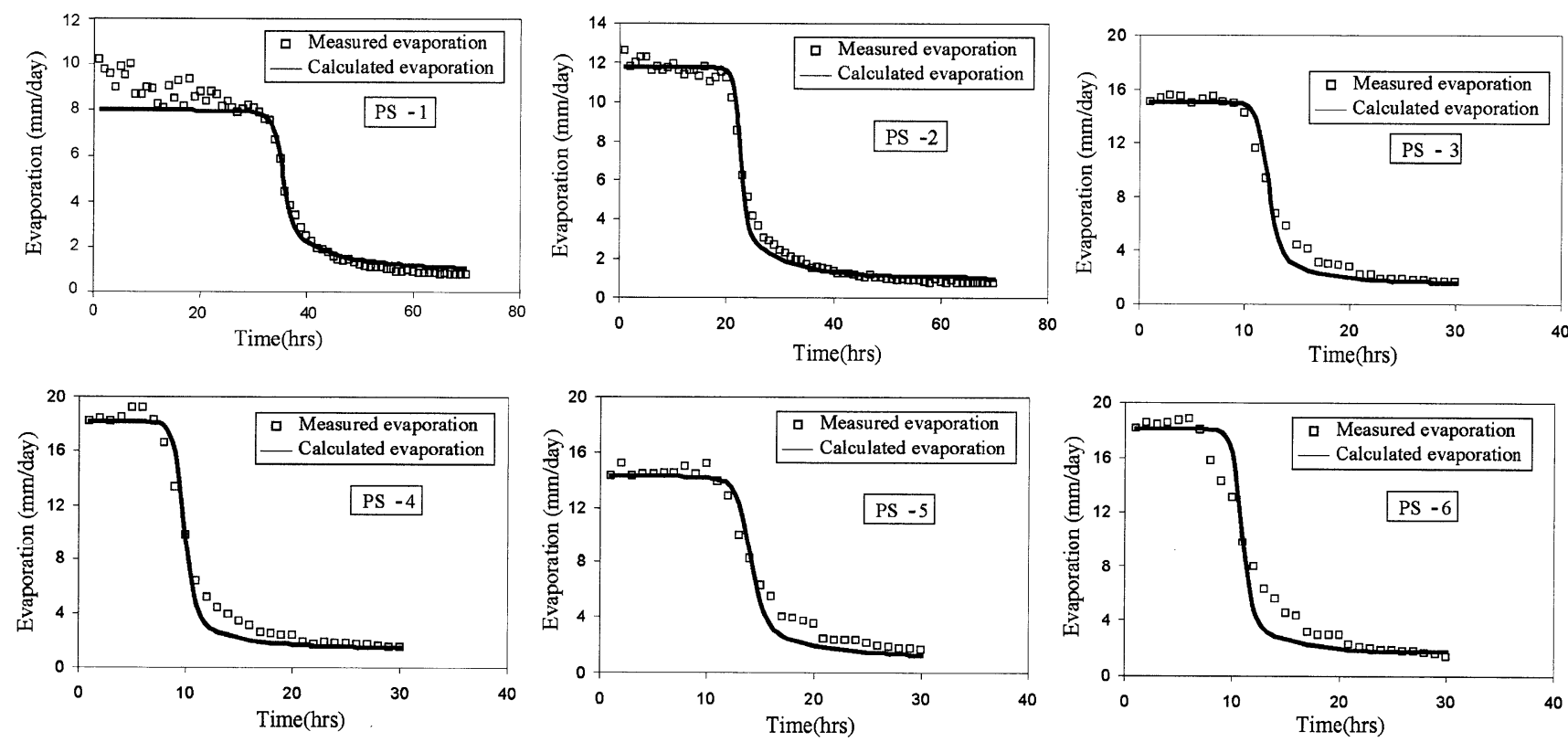

(a) Experiment- I
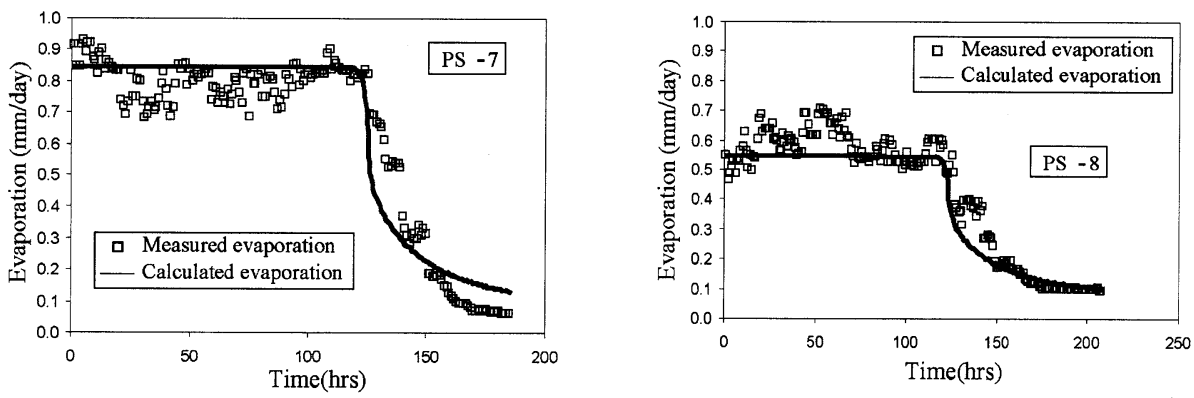

(b) Experiment-II

Fig. 10 Measured and calculated evaporation rates for the pumice tuff specimens

The GA started with large variation of $S S D$ values. However, after 23 generations the variation of $S S D$ became small. This feature implies that the convergence of GA is very high.
The comparison between the measured evaporation rates and the simulated evaporation rates (solid lines) during the time of two experiments for the sandstone and pumice tuff 

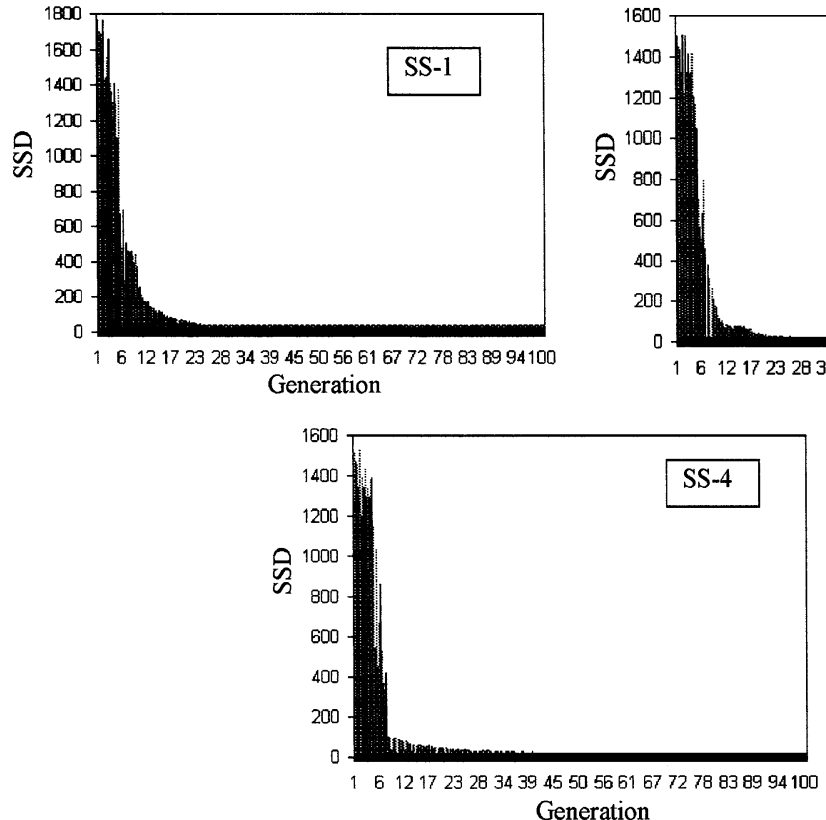

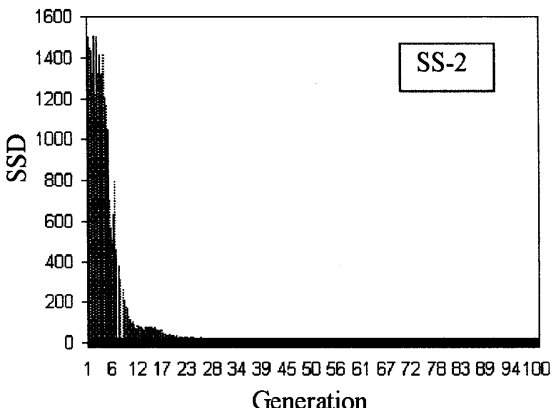

Generation
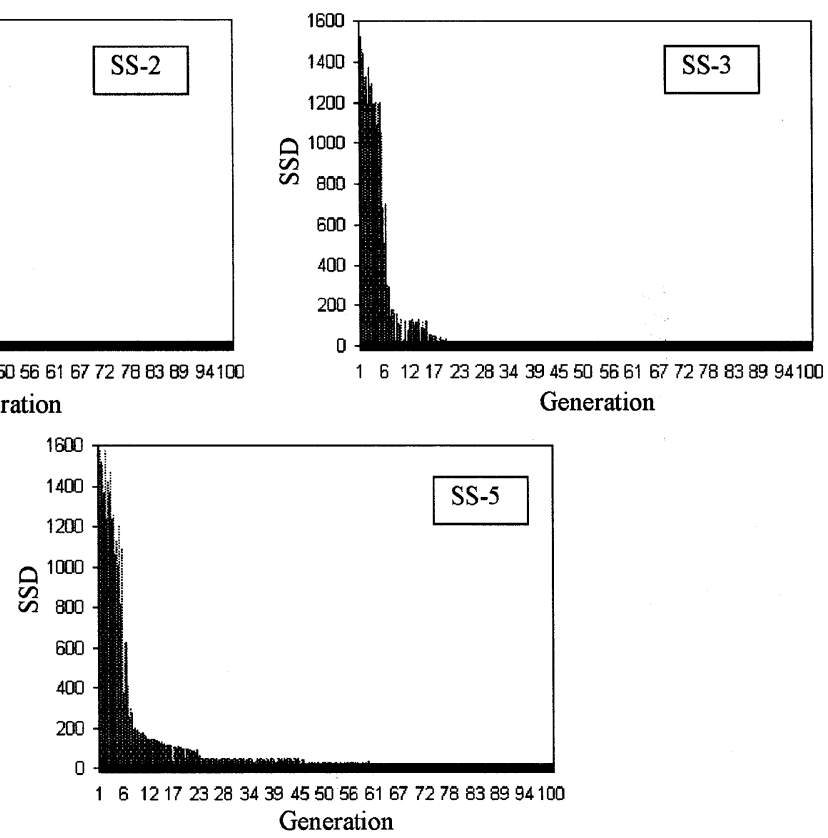

Fig. 11 Relation between generations and the SSD values in GA calculation for the sandstone specimens (Experiment-I)
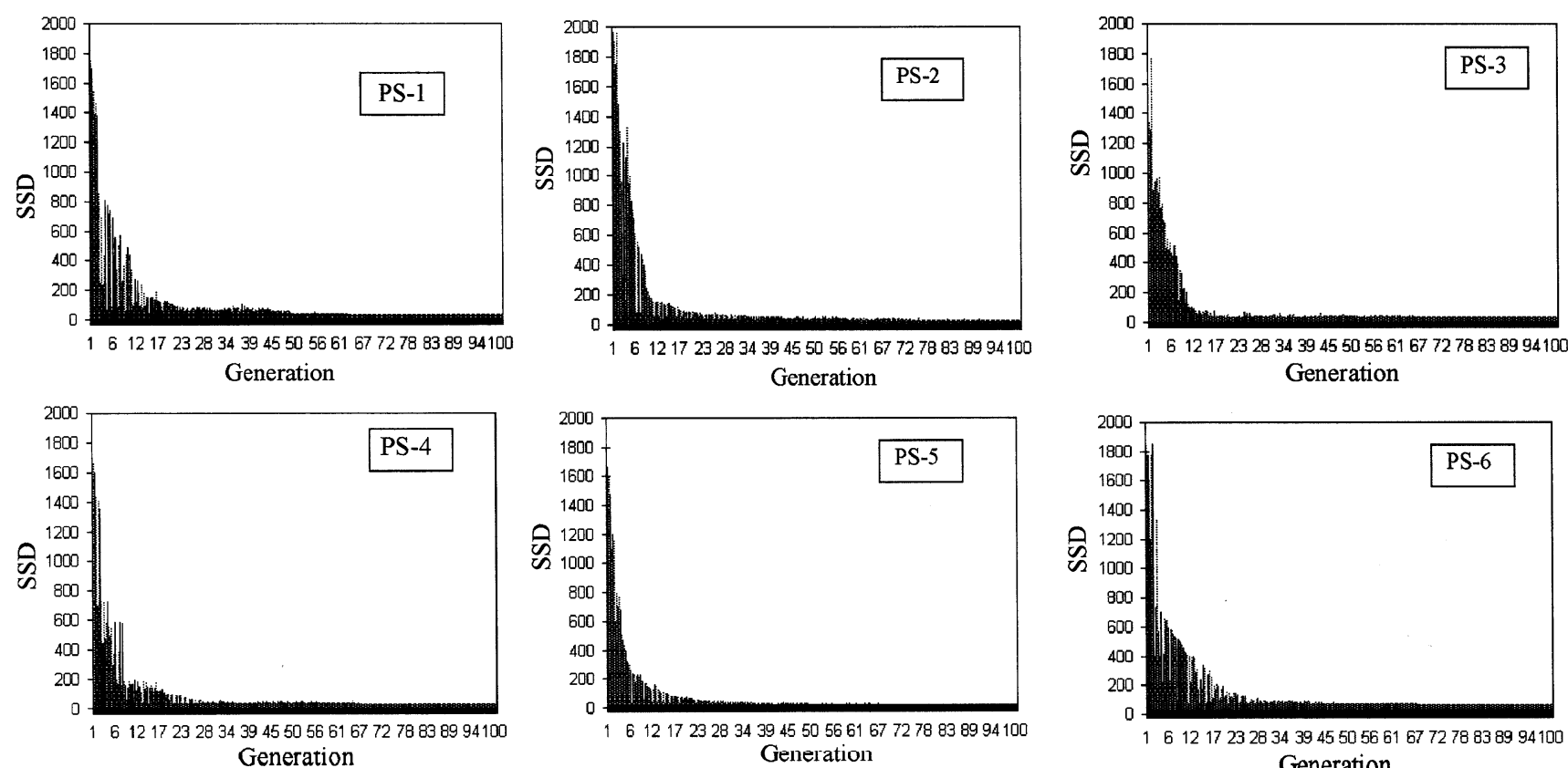

(a) Experiment-I
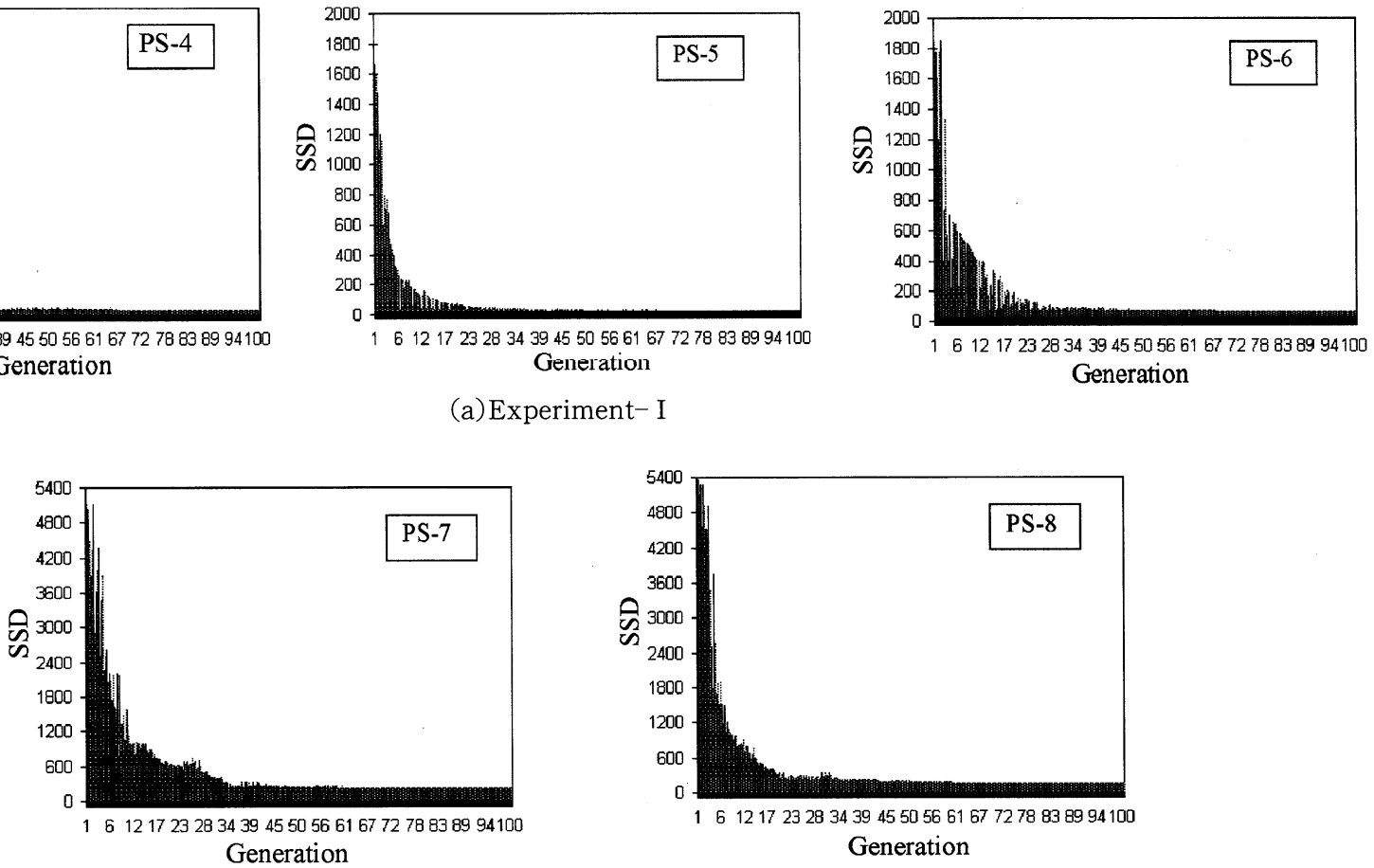

(b) Experiment-II

Fig. 12 Relation between generations and the SSD values in GA calculations for the pumice tuff specimens 
specimens are also presented in Fig. 9, 10.a and 10.b. Those figures show that calculated values are in good agreement with the measured ones. We calculated the coefficient of determination is that, the goodness of fit statistic $\left(R^{2}\right)$ is varied 0.98 to 0.99 with a mean value of 0.99 for the sandstone specimens and from 0.95 to 0.99 with the mean value of 0.97 for the pumice tuff specimens. However, there is a little difference between measured and calculated evaporation when the evaporation rates becomes very small. Small evaporation rate implies that the water content of specimen is small and the water particle is tightly kept on the mineral surface. In this region, unsaturated hydraulic properties may not be well estimated by Campbell model. On this point, whether Campbell model can be practical to apply the highly dried soft rock could be investigated in the further research.

\subsection{Fitness parameters of Campbell model and estimating unsaturated hydraulic properties}

The best parameters of Campbell model fitting for the results of experiment-I are summarized in Table 2. From this table, it can be noticed that the parameters of the Campbell model $\left(b\right.$ and $\left.\Psi_{\mathrm{e}}\right)$ are scattered to some extent. The results from experiment-I, the value of first parameter of the Campbell model (b) for the sandstone specimens is generally smaller than value for the pumice tuff specimens. On the other hand, the second parameter values $\left(\Psi_{\mathrm{e}}\right)$ of sandstone specimens seem to be greater than the average value of pumice tuff specimens. There may be several reasons on the difference of Campbell parameters between sandstone specimens and pumice tu1ff specimens. Basically Campbell model is a physical-base model which uses an analogy of average pore and particle radii distribution to the water content relations based on capillary concepts $^{13), 15)}$. So that parameters of Campbell model mainly depends on the grain size fraction, porosity, organic carbon content, saturated hydraulic conductivity, etc. in the rock specimens. From the Table 1 it is clearly seem that, porosity and saturated hydraulic conductivity of sandstone and pumice tuff specimens are different to each other. And also the pore/particle size distribution between sandstone and pumice tuff specimens is different to each other (i.e. sandstone specimens are not include the pumice, see Fig. 7 and 8). For these reasons, the parameters of sandstone specimens are different from pumice tuff specimens due to
Table 2 Best fitness parameters of the Campbell model for Experiment-I

\begin{tabular}{lcc}
\hline Sample Name & Rock Parameter $(b)$ & Air entry value $\left(\psi_{\mathrm{e}}\right)(\mathrm{J} / \mathrm{Kg})$ \\
\hline & & \\
SS-1 & 1.61 & -40.00 \\
SS-2 & 1.94 & -39.10 \\
SS-3 & 2.10 & -39.50 \\
SS-4 & 1.75 & -35.65 \\
SS-5 & 1.53 & -27.70 \\
PS-1 & 2.80 & -39.90 \\
PS-2 & 2.40 & -24.80 \\
PS-3 & 3.90 & -17.20 \\
PS-4 & 3.90 & -17.90 \\
PS-5 & 4.80 & -39.90 \\
PS-6 & 2.50 & -17.10 \\
\hline
\end{tabular}

Table 3 Best fitness parameters of the Campbell model for Experiment-II

\begin{tabular}{lcc}
\hline Sample Name & Rock Parameter $(\mathrm{b})$ & Air entry value $\left(\psi_{\mathrm{e}}\right)(\mathrm{J} / \mathrm{kg})$ \\
\hline PS-7 & 2.01 & -45.00 \\
PS-8 & 2.10 & -45.00 \\
\hline
\end{tabular}

the change of physical properties and different pore/particle size distribution. The best Campbell model parameters fitting for experiment-II is given in Table 3. From this table, it can be observed that the first parameter of Campbell model (b) evaluated by experiment-II is slightly smaller than experiment-I. On the other hand, the second parameter $\left(\Psi_{\mathrm{e}}\right)$ by experiment-II is larger than experiment-I. There may be several reasons for the difference of estimated values by experiment-I and experi-ment-II. The first possible reason may be attributed to the difference of temperature, because the suction force, viscosity of water, etc. are influenced with temperature. Second reason may be due to the change of relative humidity variation in the experiment-II. The relative humidity variation in the experiment-II is much influence on the vapor flux (evaporation rate). Under the condition of the changing evaporation rates, the estimation seems not to be good. For checking the nature, we examined the difference of Campbell model's parameter values with using same rock specimen. Table 4 shows the best fitting parameters of pumice tuff specimen (PS-8) for experiment-I and experiment-II. From this table, it is clearly verified that the first parameter $(b)$ evaluated by experiment-II is slightly smaller and second parameter $\left(\Psi_{\mathrm{e}}\right)$ by experiment-II is larger compare to experiment-I because different experimental conditions and assumptions used in the calculations. On this point, more investigation of these assumption measurements could be needed in the further studies. Fig. 13 show the unsaturated hydraulic properties (the relation between capillary head and relative hydraulic 
conductivity) of pumice tuff specimen (PS-8) for both experiments to examine the effect of the difference. In this figure it is clearly observed that the variation of capillary head and relative hydraulic conductivity between experiment-I and experiment-II are very small in middle to

Table 4 Best fitness parameters of pumice tuff (PS-8) for Experiment-I and Experiment-II

Experiment type Rock Parameter (b) Air entry value $\left(\psi_{\mathrm{e}}\right)(\mathrm{J} / \mathrm{kg})$

\begin{tabular}{lll} 
Exp-I & 2.98 & -29.87 \\
Exp-II & 2.10 & -45.00 \\
\hline
\end{tabular}

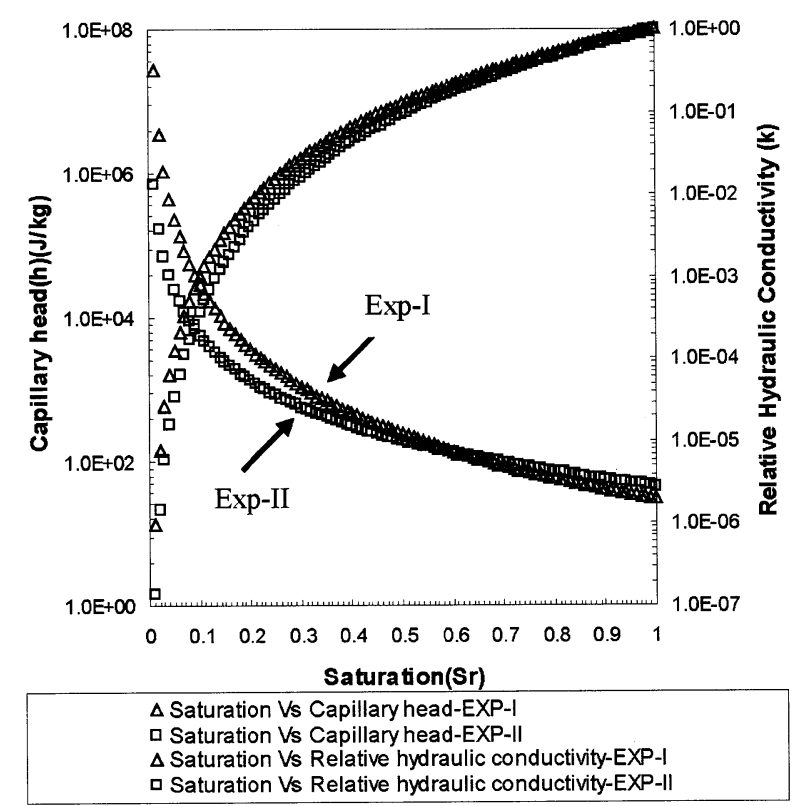

Fig. 13 Relation between capillary head and relative hydraulic conductivity of pumice tuff specimen (PS-8) for both experiments (Exp-I and Exp-II)

(a)

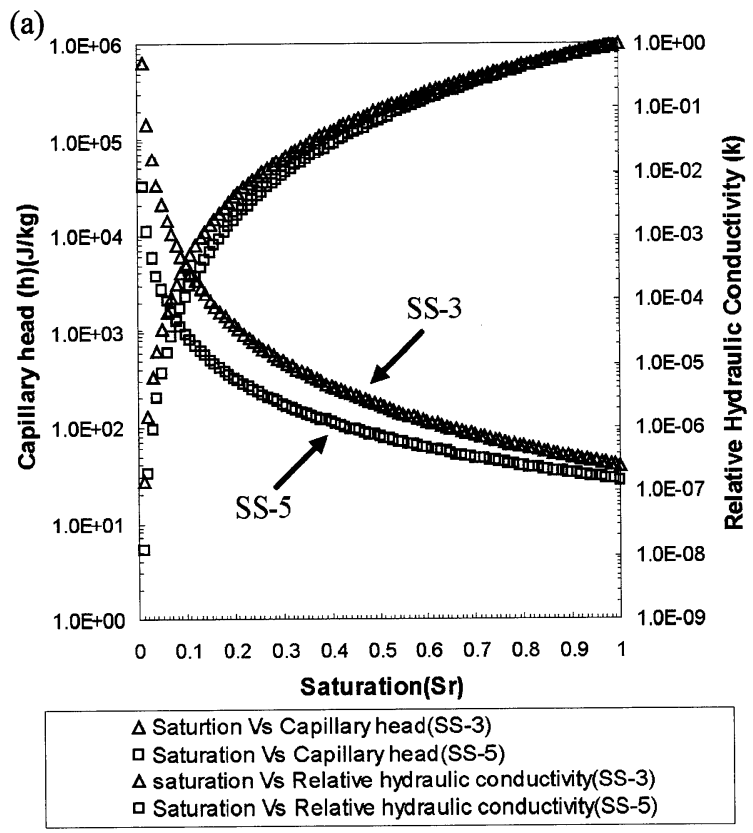

high saturation region (i.e. between 1 and 0.3). For the reason, it can be said that the unsaturated hydraulic properties are not so much difference in the saturation region larger than 0.3. As mentioned before, the Campbell model itself may not be applied for the dried condition. The relation between capillary head $(h)$ and relative hydraulic conductivity $(k)$ of sand stone and pumice tuff specimen are shown in Fig. 14.a and 14.b. In these figures, it is clearly found that the unsaturated hydraulic properties variations in pumice tuff specimens (PS) are lager than sandstone specimens (SS).

\section{Conclusion}

The major objectives of this study were; 1 ) the applicability of the Campbell model to the soft rock and 2) the performance of GA technique for estimating the parameters included in the Campbell model. Two transient evaporation tests (i.e. experiment-I and experiment-II) were proposed and carried out in this study by using 13 specimens of soft rock (5 sandstone and 8 pumice tuff specimens). As the result, it was clearly found that the transient change of evaporation rates could be well analyzed and calculated by the Campbell model. This fact implies that the Campbell model can be applied to soft rock as the first approximation. And it was also found that GA can be applied for estimating the Campbell's parameters. The convergence in the parameter estimation by GA was good and it was concluded that GA is a

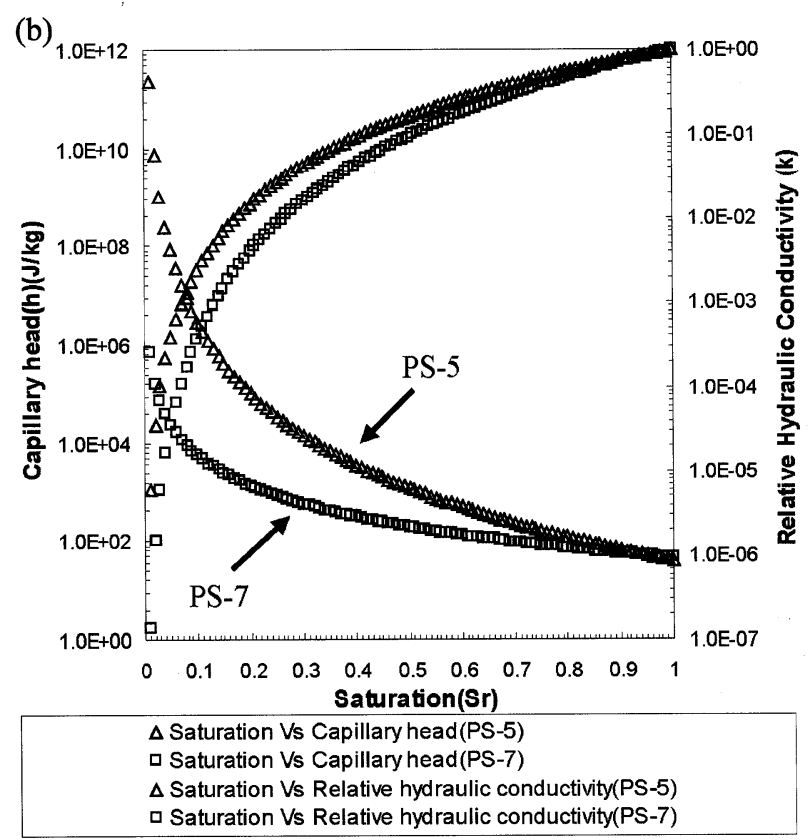

Fig. 14 Relation between capillary head and relative hydraulic conductivity

(a) For sandstone specimens, (b) For pumice tuff specimens 
promising technique for parameters estimation in the inverse solution method. It could be concluded that the techniques are practical and has potential implication for estimating the unsaturated hydraulic properties of soft rock. Although unsaturated hydraulic properties parameters can be evaluated by this technique, there are remaining some problems to be over come; 1) estimation for $h_{\mathrm{a}}$ and $T_{\mathrm{s}}$ in the experiments, 2) estimation for the low saturation conditions of soft rock. These problems must be studied in the future.

\section{References}

1) BRUCE, R. R. and KLUTE, K. (1956): The measurement of soil water diffusivity, Soil Sci. Am. Proc, Vol.20, pp.458462.

2) GARDNER, W. R. and MIKLICH, F. J. (1962) : Unsaturated conductivity and diffusivity measurements by a constant flux method, Soil Sci, Vol.93, pp.271-274.

3) KOOL, J. B., PARKER, J. C. and VAN GENUCHTEN, M. Th. (1985) : Determining soil hydraulic properties from one-step outflow experiments by parameter estimation, I. Theory and numerical studies, Soil Sci. Soc. Am. J, Vol.49, pp.1348-1354.

4) KOOL, J. B. and PARKER, J. C. (1988): Analysis of the inverse problem for transient unsaturated flow, Water Resour. Res., Vol.24, pp.817-830.

5) ECHING, S. O., HOPMANS, J. W. and WENDROTH, O. (1994) : Unsaturated hydraulic conductivity from transient multi-step outflow and soil water pressure data, Soil Sci. Soc. Am. J, Vol.58, pp.687-695.

6) WATANABE, K., HAMADA, S., SAKAI, T. and HOSHINO, Y. (1995): In-situ and laboratory tests for estimating the hydraulic properties of unsaturated rock, Proc. Inter. Congr. on Rock Mech., Japan, Vol.2, pp.725-728.

7) VAN DAM, J. C., STICKER, J. N. M. and DROOGERS, P. (1994) : Inverse method to determine soil hydraulic functions from multi-step outflow experiments, Soil Sci. Soc. Am. J, Vol.58, pp.647-652.

8) ALI, A. M., OZAKI, T., HASHEM, M. and WATANABE, K. (2000) : New method for determining hydraulic properties of unsaturated soil using evaporation data, Annual journal of hydraulic engineering, JSCE, Vol.44, pp.205-210.

9) FUJIMAKI, H. and INOUE, M. (2003) : A transient evaporation method for determining soil hydraulic properties at low pressure, Soil Sci. Soc. Vadose Zone. J, Vol.2, pp.400-4008.

10) RICHARDS, L. A. (1931) : Capillary conduction of liquids in porous mediums, Physics (NY), pp.318-333.

11) BROOKS, R. H. and COREY, A. T. (1964): Hydraulic properties of porous media, Hydrol. Pap. No. 3. Colorado State Univ., Fort Collins, CO.

12) MUALEM, Y. (1976) : A new model for predicting the hydraulic conductivity of unsaturated porous media, Water Resour. Res., Vol.12, pp.513-522.

13). CAMPBELL, G. S. (1974) : A simple method for determining unsaturated conductivity from the moisture retention data, Soil Sci., Vol.117, pp.311-314.

14) VAN GENCHTEN, M. Th. (1980) : A closed-form equation for the predicting the hydraulic conductivity of unsaturated soils, Soil Sci. Soc. Am. J., Vol.44, pp.892-898.

15) CAMPBELL, G. S. (1985) : Soil physics with BASIC:
Transport models for soil-plant systems, Elsevier, Amsterdam, Netherlands.

16) SIMUNEK, J. and HOPMANS, J. W. (2002) : Parameter optimization and nonlinear fitting, Soil Sci., America Book Series, Vol.5, pp.139-157.

17) GWO, J. (2001) : In search of preferential flow paths in structured porous media using a simple genetic algorithm, Water Resour. Res., Vol.37, pp.1589-1601.

18) KARPOUZOS, D. K., DELAY, F., KATSIFARAKIS, K. L. and MARSILY, G. A. De. (2001) : Multipopulation genetic algorithm to solve the inverse problem in hydrogeology, Water Resour. Res., Vol.37, pp.2291-2302.

19) AMOR V. M. and DROOGERS, P. (2002) : Inverse modeling in estimation soil hydraulic functions: a Genetic Algorithm approach, J. Hydrology and Earth System Sciences, Vol.6 (1), pp.49-65.

20) UNSAL, E., DANE, J. H. and DOZIER, G. V. (2005) : A genetic algorithm for predicting pore geometry based on air permeability measurements, Soil Sci. Soc., Vadose Zone J., Vol.4, pp.389-397.

21) SOHAIL, A., WATANABE, K. and TAKEUCHI, S. (2006) : Stream flow forecasting by artificial neural network (ANN) model trained by real coded genetic algorithm (GA), J. of JAGH, Vol.48, No.4, pp.233-262.

22) WATANABE, K. (1989) : Evaporation measurement for mapping the ground water discharge on the tunnel wall, Part 1, J. of JSGE, Vol.30, pp.247-253

23) WATANABE, K. (1991) : Evaporation measurement in validation drift. Part 1, Stripa Technical Report, pp.1-131.

24) KYI MYINT THWIN, WATANABE, K., KHANCHAI, C. and AYE AYE THANT. (2002) : Estimation of transpiration from a tree by using two-sensor type evaporation meter, Annual Journal of Hydraulic Engineering, JSCE, Vol.46, pp.61-66.

25) ECHING, S. O. and HOPMANS, J. W. (1993) : Optimization of hydraulic functions from transient outflow and soil water pressure data, Soil Sci. Soc. Am. J., Vol.57, pp.11671175.

26) HASSAN, I. M. and ALI, A. M. (2002) : An inverse method for determining unsaturated soil hydraulic functions from unsteady upward flow, Journal of Engineering Science, Assiut University, Egypt, Vol.32, pp.1115-1128.

27) HOLLAND, J. H. (1975) : Adaptation in Natural and Artificial Systems, University of Michigian Press, Ann Arbor, MI , pp.183

28) GOLDBERG, D. E. (1989) : Genetic algorithms in search, optimization, and machine learning, 2nd edition. Addison-Wesley, Reading, Mass.

29) MITCHELL, M. (1996) : An introduction to genetic algorithms, The MIT press, Cambridge, Massachusetts, London, England, p.205.

30) RANDY, L. H., and SUE, E. H. (1998) : Practical genetic algorithms, John Wiley and Sons, Inc., New York, pp.177.

31) DOZIER, G., HOMAIFAR, A., TUNSTEL, E. and BATTLE, D. (2000) : An introduction to evolutionary computation, In A. Zilouchian and M. Jamshidi (ed.), Intelligent control systems using soft computing methodologies. CRC Press, New York, pp.365-379.

32) DAVIS, L. (1991) : Handbook of genetic algorithms. Van Nostrand Reinhold, New York.

33) ROOIJ, A. J. F. V., JAIN, L. C., and JOHNSON, R. P. (1996): Neural network training using genetic algorithm, World Scientific Publishing Co. Pte. Ltd., p.130.

34) DANDY, G. C., SIMPSON, A. R., and MURPHY, L. J. (1996): An improved genetic algorithm for pipe network optimization. Water Resour Res., Vol.32 (2), pp.449-458. 
Jour. Japan Soc. Eng. Geol., Vol.49, No.2, pp.64-77, 2008

\title{
遺伝的アルゴリズム $(\mathrm{GA})$ と逆解析を用いた不飽和軟岩の透水性評価
}

\author{
Min MAUNG MAUNG・渡辺邦夫・佐々木泰・長田昌彦
}

\section{要 旨}

軟岩の不飽和透水特性(水分特性曲線之透水係数の飽和度依存性の関係) は, トンネルや岩盤表面近傍などの飽和・不飽和地下 水解析する場合, 妥当に評価する必要がある. 本研究では, この不飽和特性を, キャンベルモデルと遺伝的アルゴリズム(GA)を 用いて推定する実用的な方法を開発した. 本研究の主目的は二つあり，一つは，キャンベルモデルが軟岩の不飽和特性評価に適 用できるかを調べることである. 二つめの目的は, キャンベルモデルに含まれる二つのパラメーター推定に, 遺伝的アルゴリズ ムがどの程度適用できるかを調べることである.これらのパラメーター推定を, 青森県六ヶ所村から採取したディスク状に加工 した第三紀堆積軟岩表面からの蒸発量変化を逆解析することで行った. 本研究では, 環境条件の異なる場で行う二つの蒸発变化 実験方法を提案した。これらの実験を用いて，5個の砂岩，8個の凝灰岩試料のパラメーターを推定した.

研究の結果, まず, 蒸発量の非定常変化が, 試料の飽和度が小さい範囲を除いて, キャンベルモデルを用いて解析しうること が明らかとなった. また, 遺伝的アルゴリズムが, 逆推定にうまく用いうることが明らかとなった. さらに, 提案する方法が軟 岩の不飽和特性評価上実用性が高いことがわかった。

キーワード : 不飽和透水特性, キャンベルモデル, 蒸発量計測, 遺伝的アルゴリズム 